\title{
A microencapsulation process of liquid mercury by sulfur polymer stabilization/solidification technology. Part I: Characterization of materials $(\cdot)$
}

\author{
A. López-Delgado*, F. A. López*, F. J. Alguacil*, I. Padilla* and A. Guerrero**
}

\begin{abstract}
European Directives consider mercury a priority hazardous substance due to its adverse effects on human health and the environment. In response to environmental concerns, a microencapsulation process has been developed within the European LIFE program as a long-term storage option for mercury. This process leads to the obtainment of a stable concrete-like sulfur matrix that allows the immobilization of mercury. The final product, in the form of a solid block containing up to $30 \% \mathrm{Hg}$, exhibits excellent mechanical properties (compressive strength 53-61 MPa and flexural strength $7-10 \mathrm{MPa})$, low porosity $\left(0.57 \% \mathrm{P}_{\mathrm{He}}\right)$, very low total pore volume $\left(0.63 \times 10^{-2} \mathrm{~cm}^{3} \mathrm{~g}^{-1}\right)$, and extremely low permeability (coefficient of water absorption by capillarity $0.07 \mathrm{~g} \mathrm{~cm}^{-2}$ ). Toxicity characteristic leaching tests reveal a mercury concentration in leachates well below the $0.2 \mathrm{mg} \mathrm{L}^{-1}$ set out in US EPA Land Disposal Restrictions (LDRs). The values of mercury vapor emissions of final products were lower than those of cinnabar and metacinnabar.
\end{abstract} emission.

\section{Proceso de microencapsulación de mercurio líquido mediante tecnología de estabilización/solidificación con azufre polimérico. Parte I: Caracterización de materiales}

Resumen

Palabras clave:

\begin{abstract}
Las Directivas Europeas consideran al mercurio una sustancia de peligrosidad prioritaria debido a sus efectos adversos sobre la salud humana y sobre el medio ambiente. En respuesta a estas preocupaciones ambientales, y dentro del Programa Europeo LIFE, se ha desarrollado un proceso de microencapsulación como una opción al almacenamiento a largo plazo del mercurio. Con este proceso se obtiene un material estable, tipo concreto, de matriz de azufre que permite la inmovilización del mercurio. El producto final, en forma de un bloque sólido, contiene hasta un $30 \%$ de $\mathrm{Hg}$, presenta excelentes propiedades mecánicas (resistencia a la compresión 53-61 MPa, y a la flexión 7-10 MPa), baja porosidad $\left(0,57 \% \mathrm{P}_{\mathrm{He}}\right)$, muy bajo volumen total de poro $\left(0,63 \times 10^{-2} \mathrm{~cm}^{3} \mathrm{~g}^{-1}\right)$ y una permeabilidad extremadamente baja (coeficiente de absorción de agua por capilaridad $0,07 \mathrm{~g} \mathrm{~cm}^{-2}$ ). Las características de toxicidad determinadas mediante los ensayos de lixiviación indican una concentración de mercurio en los lixiviados muy por debajo de los límites $\left(<0,2 \mathrm{mg} \mathrm{L}^{-1}\right)$ establecidos por la Normativa de Restricción de Disposición de Residuos en el Suelo de EE.UU (US EPA Land Disposal Restrictions, LDRs). También se han determinado las emisiones de vapor de mercurio en los productos finales obteniéndose valores más bajos que en muestras de cinabrio y metacinabrio.
\end{abstract}

Mercurio; Metacinabrio; Estabilización/solidificación con azufre polimérico; Microencapsulación; Lixiviación; Emisiones de mercurio.

\section{INTRODUCTION}

The issue of mercury waste management has been a matter of concern for several decades. Mercury waste is subjected to strict health, safety and environmental legislation, especially in industrialized countries, due to its highly toxic nature. Mercury, a liquid at ambient temperature,

\footnotetext{
(·) Trabajo recibido el día 29 de julio de 2011 y aceptado en su forma final el día 20 de diciembre de 2011.

* National Centre for Metallurgical Research, CSIC. Avda. Gregorio del Amo, 8. 28040 Madrid, Spain. Corresponding Author: alopezdelgado@cenim.csic.es

** Eduardo Torroja Institute for Construction Science, CSIC. C/ Serrano Galvache, 4. 28033 Madrid, Spain.
} 
has a low but significant vapor pressure which originates its high toxicity. The United Nations Environment Program (UNEP) established its Mercury Program with the aim of delivering activities on mercury and to support negotiations of an international instrument for its control. Thus a series of Governing Council Decisions have been established from 2001 which include prevention, minimization and management of mercury waste and also its long-term storage and disposal ${ }^{[1]}$. European legislation ${ }^{[2]}$ considers mercury to be a priority hazardous substance due to its adverse effects on human health and the environment, and indeed a world-wide common effort is now on to reduce both the supply and demand of mercury. EU Council and European Parliament Regulation $1102 / 2008^{[3]}$ sets 2011 as the cut-off date for industrial use of $\mathrm{Hg}$ and the banning of mercury exports and addresses the issue of safe storage of metallic mercury. The export ban came into force on 15 March 2011 and affects metallic mercury, cinnabar ore, mercury (I) chloride, mercury (II) chloride, and mixtures of metallic mercury with other substances including mercury alloys. As a result, all excess $\mathrm{Hg}$ must be stored in safe conditions in secure places until definitive stabilization policies are established ${ }^{[4}$ and 5$]$.

A number of authors have developed methods for stabilizing mercury by means of the formation of mercuric sulfide. Svensson et al. ${ }^{[6]}$ studied a process to form cinnabar from a mixture of elemental mercury or solid mercury oxide and solid sulfur or iron sulfide. López et al. ${ }^{[7]}$ in a previous paper described a simple process to form metacinnabar from direct reaction between liquid mercury and elemental sulfur, using the mechanical energy provided by a ball mill.

If stabilization is a chemical method that achieves chemical immobilization by the formation of stable or non-water soluble compounds, to encapsulate means to embed within a stable matrix. Melting and casting are part of the encapsulation process, which is based on solidification and/or chemical stabilization technologies. The objective of these methods is to isolate the waste from the surrounding environment by substantially reducing the area exposed to potential leaching media ${ }^{[8]}$. This kind of combined technology is referred to in the literature as a stabilization/ solidification S/S process ${ }^{[9]}$. S/S is accepted as a well-established disposal technique for the treatment of hazardous waste. The degree of effectiveness of S/S products is basically defined by two parameters: strength and leaching resistance; the former as an indicator of solidification and the latter is used to assess the extent of fixation ${ }^{[10}$ and 11$]$. Conventional S/S technologies based on cement-like materials fail to effectively reduce the leachability of mercury because this metal tends to hydrolyze to form mercuric oxide and thus maintains a strong potential to volatilize ${ }^{[12]}$. Consequently, a number of S/S-based technologies have been developed in a search for alternatives to cement. Sulfur polymer stabilization/solidification technology (SPSS) is proving to be a promising $\mathrm{S} / \mathrm{S}$ technology for the long-term storage of mercury. It is based on the use of so-called sulfur polymer cement (SPC), a thermoplastic material manufactured by several companies and marketed under several trade names ${ }^{[13}$ and 14$]$. Johnson et al. ${ }^{[15]}$ report a method for encapsulating solid mercury waste using a liquid polysulfide polymer and an oxidative curing agent $\left(\mathrm{MnO}_{2}, \mathrm{PbO}_{2}\right.$, calcium peroxide, zinc peroxide, sodium perborate, ammonium dichromate and cumene hydroperoxide). The solid waste is immersed in the liquid polysulfide and in special curing conditions the mixture hardens to produce a solid encapsulation product. An oxidative curing agent causes cross linking and hardening of the polysulfide polymer. Kalb et al. ${ }^{[16]}$ and Furhmann et al. ${ }^{[17]}$ developed a method for treating mercurycontaining waste in a single reaction vessel in two steps: a) stabilizing the waste with sulfur polymer cement in an inert atmosphere to form a chemically stabilized mixture; and b) encapsulating the mixture by heating to form a molten product which is cast to obtain a monolithic final waste form. Additional sulfur polymer cement can be added in the encapsulation step if needed and a stabilizing additive can be added in the process to improve the leaching properties of the waste form. The stabilization step includes combining mercury containing waste with sulfur polymer cement in an inert atmosphere $\left(\mathrm{Ar}, \mathrm{N}_{2}\right)$. A stabilizing agent (sodium sulfide, triisobutyl phosphine sulfide, calcium hydroxide, sodium hydroxide, calcium oxide and magnesium oxide, or a combination thereof) is added to the mercury-containing waste and sulfur cement.

This paper describes the development of a batchtype microencapsulation process for liquid mercury from the chloralkali industry by means of the use of SPSS technology ${ }^{[18 \text { and } 19]}$. This study forms part of the European MERSADE project (LIFE06 ENV/ES/PRE/03) for the design, construction and validation of a pilot installation for the safe deposit of mercury. The project also includes the development of a process for the stabilization/ solidification of liquid mercury by the use of polymeric sulfur cement. On the basis of this research, Part I of this work deals with the description of the process, the characterization of 
the materials obtained and the study of the mechanical and physical properties of the concretelike solid blocks produced. Leachability and vapor mercury emissions are also determined in this Part I, in order to verify that the SPSS process employed renders inert materials. The determination of the long-term durability of the materials, based on their behavior in different aggressive environment will be described in Part II of this study.

\section{EXPERIMENTAL}

\subsection{Materials}

Liquid mercury from the chloralkali industry supplied by local mining company, Minas de Almadén y Arrayanes S.A. (Mayasa, Almadén, Spain) and granular sulfur (99.4 \% wt, size $<60 \mu \mathrm{m}$, type Rubber Sul 10) supplied by Repsol YPF (Madrid, Spain) were milled in a ball mill at $400 \mathrm{rpm}$ for $60 \mathrm{~min}$ to prepare $\mathrm{HgS}$-metacinnabar (molar ratio $\mathrm{Hg} / \mathrm{S}$ of $1 / 1$ ), according to the process described by López et al. ${ }^{[7]}$. Due to the grinding jar size $(250 \mathrm{ml})$ of the planetary ball mill (FRISTSCH mod. Pulverisette 6), batches of $120 \mathrm{~g}$ of metacinnabar were prepared up to the amount required for the encapsulation process.

Commercial gravel $(<6.3 \mathrm{~mm})$, siliceous sand $(<4 \mathrm{~mm})$ were used as aggregate (inert) materials and $\mathrm{CaCO}_{3}(<0.125 \mathrm{~mm})$ was used as filler. A sulfurcontaining polymer $\left(\mathrm{STX}^{\mathrm{TM}}\right.$ supplied by Starcrete ${ }^{\mathrm{TM}}$ Technologies Inc. Quebec, Canada) was used as thermoplastic material ${ }^{[14]}$; this kind of material is commonly referred to in the literature as sulfur polymer cement (SPC), but it is not a cementitious material ${ }^{[9]}$.

\subsection{Experimental procedure}

In order to achieve a final product with the characteristics of a concrete-like material, both the grain size of all the components and their corresponding percentages in the mixture were designed according to the Spanish standard for structural concretes ${ }^{[20]}$. The granulometric distribution curves for the different components, calculated by Fuller's equation, are shown in figure 1 . The gravel/sand/filler ratio was maintained constant at 30/60/10 wt/wt/wt for all the samples.

A mixture of $S$ and SPC (10/1 wt/wt) was previously heated to $145^{\circ} \mathrm{C}$ and then cooled to room temperature, milled and characterized.

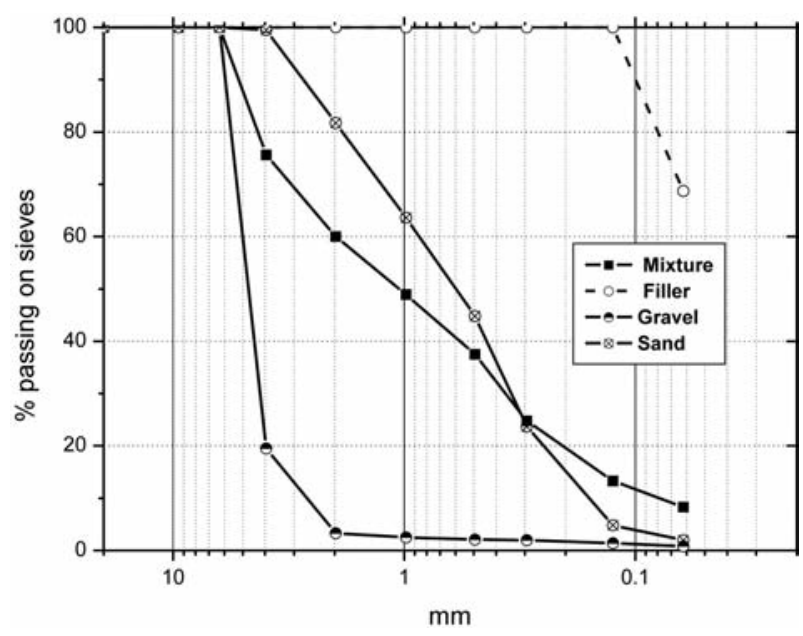

Figure 1. Grain size distribution of the different inert materials used (sand, gravel, filler) and curve of the final mixture.

Figura 1. Distribución del tamaño de grano de los diferentes materiales inertes utilizados (arena, grava, fino) y curva de la mezcla final.

The scheme of the developed sulfur polymer stabilization/solidification (SPSS) process is shown in figure 2. Mixtures of metacinnabar, inert materials and filler were heated to $145^{\circ} \mathrm{C}$ and stirred for 30 min using a mixer with a temperature controller (IBERTEST Mod. 16-L0005B). The temperature was finely controlled because the viscosity of the mixture must allow its workability and handling while at the same time avoiding the thermal degradation of the thermoplastic material. The latter was added to the mixture which was then poured into stainless steel moulds and shaken on a vibrating table (PROETI H0110) at $3000 \mathrm{rpm}$ for $30 \mathrm{~s}$ in order to settle the products in the moulds. The moulds were subsequently disassembled and the samples allowed to cool to room temperature. The end product was obtained in the form of $40 \times 40 \times 160 \mathrm{~mm}$ solid blocks according to the procedure described in Spanish Patent P200930672[18].

The weight of all the components per batch was $5 \mathrm{~kg}$. Six solid blocks of around $800 \mathrm{~g}$ weight were obtained per trial. The mass percentage of liquid mercury in the mixture was varied between $5-30 \%$, which corresponds to an $\mathrm{HgS}$ percentage of between $5.8-34 \%$. The composition of all the monoliths prepared by incorporation of metacinnabar into the sulfur-concrete is shown in table $\mathrm{I}$.

The concrete-like samples obtained are hereinafter referred to as Hg5SC, Hg10SC, Hg15SC, Hg20SC, $\mathrm{Hg} 30 \mathrm{SC}$, for $\mathrm{Hg}$-S-concrete samples with 5, 10, 15, 


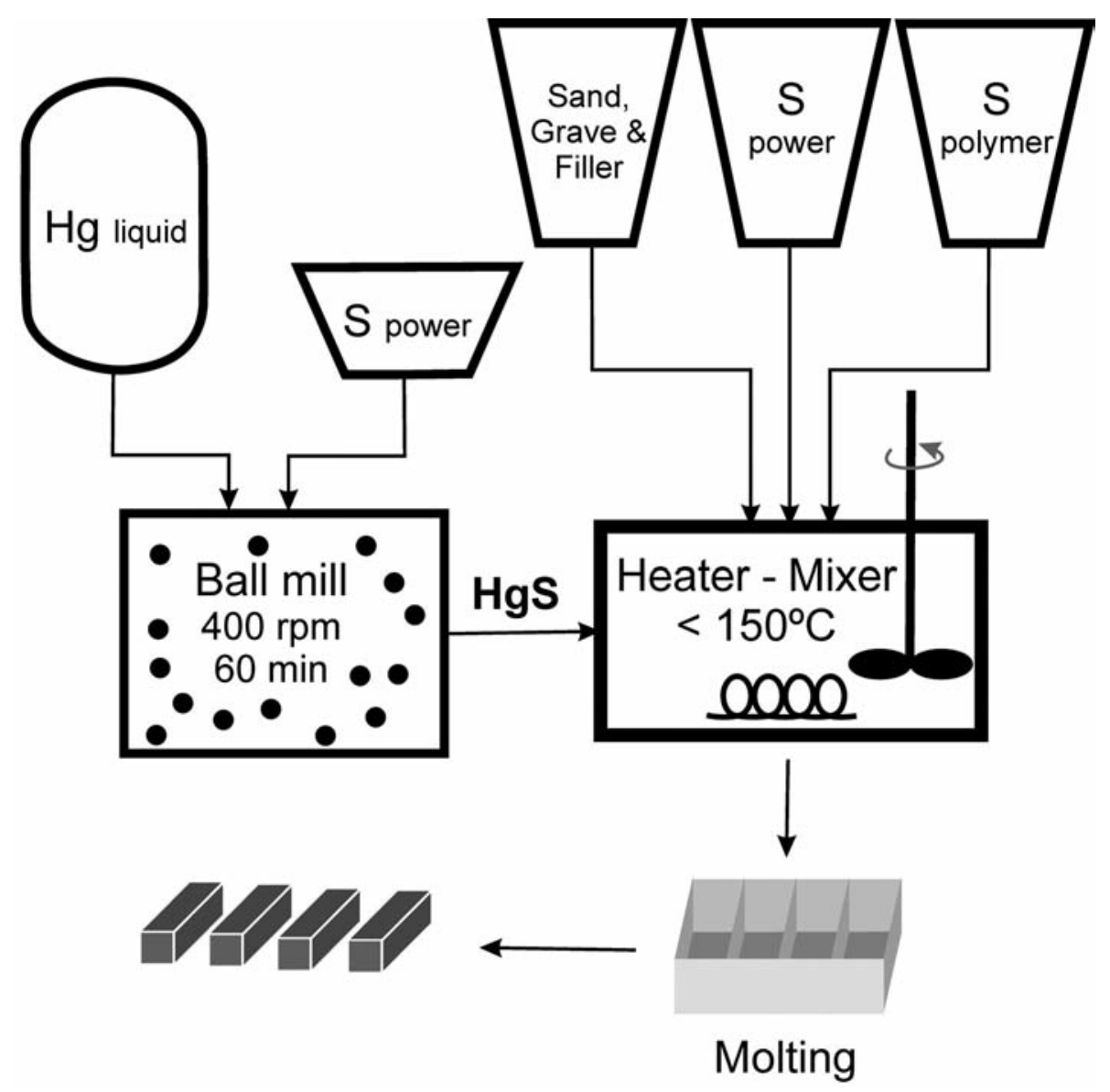

Figure 2. Scheme of the SPSS process used for the stabilization/ solidification of mercury.

Figura 2. Esquema del proceso SPSS utilizado para la estabilización/solidificación del mercurio.

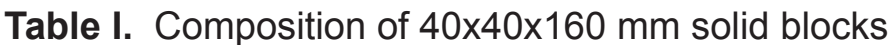
of mercury-sulfur-concrete (expressed as wt \%)

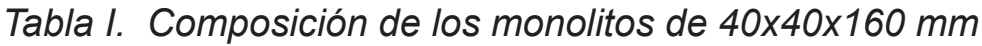
de concreto mercurio-azufre (expresado en \% en peso)

\begin{tabular}{lrrrrrr}
\hline & \multicolumn{6}{c}{ Sample } \\
\cline { 2 - 7 } Component & SC & Hg5SC & Hg10SC & Hg15SC & Hg20SC & Hg30SC \\
\hline Gravel & 25.1 & 23.3 & 21.6 & 19.8 & 18.1 & 14.61 \\
Sand & 50.1 & 46.6 & 43.1 & 39.7 & 36.2 & 29.22 \\
Filler & 8.4 & 7.8 & 7.2 & 6.6 & 6.0 & 4.87 \\
S & 15 & 15 & 15 & 15 & 15 & 15 \\
HgS & & & & & & \\
(metacinnabar) & - & 5.8 & 11.6 & 17.4 & 23.2 & 34 \\
Hg\%/equivalent & - & 5 & 10 & 15 & 20 & 30 \\
Thermoplastic & & & & & & \\
material (SPC) & 1.5 & 1.5 & 1.5 & 1.5 & 1.5 & 1.5 \\
\hline
\end{tabular}


20 and $30 \%$ mercury respectively, and SC for the mercury-free sulfur-concrete sample used as reference.

\subsection{Characterization of materials}

Prior characterization of the sulfur $(S)$ and the thermoplastic material was carried out by means of X-Ray Diffraction, (XRD, BRUKER XRD Mod. D8 Discover, $0.032 \Theta$ degree step-widths and counting time of 5 s per step), Differential Scanning Calorimetry (DSC, Setaram Sensys Evo), and Scanning Electron Microscopy, (SEM, HITACHI model S-2100) on as-obtained C-coated samples.

Morphological characterization of final products was carried out by SEM on the C-coated fracture surface. For phase identification and chemical analysis, samples were embedded in a resin and the surfaces were polished and then C-coated. A Field Emission Microscope (JEOL JSM 6500 F) provided with an Energy Dispersive Analyzer (LINK OXFORD INCA, EDAX unit) was used to determine the composition of the samples.

\subsection{Determinations of mechanical and physical properties}

The mechanical properties of the samples, such as compressive strength $\left(\mathrm{C}_{\mathrm{S}}\right)$ and flexural strength $\left(\mathrm{F}_{\mathrm{S}}\right)$, were measured according to the standard UNE EN 196-1:2005[21]. The results were obtained as an average value of six measurements performed using an Ibertest mod. Autotest 200-10-W universal press.

The bulk (apparent) density of the samples, $\rho_{b}$, was measured by a dry flow pycnometer (GeoPyc 1360). The skeleton (relative), $\rho_{\mathrm{s}}$, and real (absolute), $\rho_{\mathrm{r}}$, densities were measured by a He displacement pycnometer (AccuPyc 1330). Density values were used to determine total porosity $\left(\mathrm{P}_{\mathrm{T}}\right)$, closed porosity $\left(\mathrm{P}_{\mathrm{C}}\right)$ and open porosity to $\mathrm{He}$, according to the equations $((1)-(3))$ :

$$
\begin{gathered}
P_{T(\%)}=\left[\left(1-\frac{\rho_{b}}{\rho_{r}}\right)\right] \times 100 \\
P_{C(\%)}=\left[\left(1-\frac{\rho_{s}}{\rho_{r}}\right)\right] \times 100 \\
P_{H e(\%)}=P_{T}-P_{C}
\end{gathered}
$$

The total pore volume was determined by the equation (4):

$$
\mathrm{V}_{\mathrm{p}}=\left[\left(\frac{1}{\rho_{\mathrm{b}}}-\frac{1}{\rho_{\mathrm{r}}}\right)\right]
$$

\subsection{Leachability of mercury}

Leaching tests were carried out to examine the stability of mercury in the end products using the Toxicity Characteristic Leaching Procedure (TCLP, EPA Method 1311) ${ }^{[22]}$. Samples for testing were crushed to a grain size of less than $9.5 \mathrm{~mm}$. The extraction fluid to be employed in the TCLP test depends on the alkalinity of the sample, so a preliminary evaluation was carried out by transferring an aliquot of the sample $(5 \mathrm{~g})$ to a $500 \mathrm{ml}$ Erlenmeyer flask, adding $96.5 \mathrm{ml}$ of Milli-Q water and vigorously stirring the suspension for 5 minutes using a magnetic stirrer. The $\mathrm{pH}$ values of the samples ranged between 9.3 -9.8. A $1 \mathrm{~N} \mathrm{HCl}$ solution $(3.5 \mathrm{ml})$ was added and the samples were heated to $50^{\circ} \mathrm{C}$ for 10 minutes. The $\mathrm{pH}$ was then recorded again, yielding values between $6.9-7.8$. Thus it was determined to use fluid 2 (glacial $\mathrm{CH}_{3} \mathrm{COOH}$ with reagent water solution; with a $\mathrm{pH}$ of $2.88 \pm 0.05)$ as the extraction fluid.

Around $500 \mathrm{~g}$ of each previously crushed sample were successively quartered up to obtain representative $25 \mathrm{~g}$ samples. A modified version of the TCLP was conducted, using $25 \mathrm{~g}$ samples instead of the prescribed $100 \mathrm{~g}$. The samples were extracted with an amount of extraction fluid 2 equal to 20 times the weight of the solid. The tests were performed in triplicate. The samples were stirred for $18 \mathrm{~h}$, after which the liquid and solid phases were separated by filtration using a $47 \mathrm{~mm}$ filter holder (Millipore Corp.) with $0.45 \mu \mathrm{m}$ glass fiber filters. The filtrates were preserved by acidification with nitric acid to a $\mathrm{pH}<2$ and stored at $4{ }^{\circ} \mathrm{C}$ until the performance of $\mathrm{Hg}$ analysis.

The determination of mercury in leachates was carried out by Atomic Fluorescence ${ }^{[23]}$ in a Millennium PSA Spectrometer. Aliquots of the leachates were diluted and subjected to cold digestion with an acid/bromate/bromide mixture. Stannous chloride was added to the digested samples as a reducing agent to produce $\mathrm{Hg}^{0}$. The reduced mercury was separated from the sample/reagent mixture as a vapor and was carried to the fluorescence detector by a high purity argon stream. Extraction fluid 2 (described above) was used as a blank. The detection limit (DL) calculated on the basis of the standard deviation (SD) of ten successive measurements of the blank solution, 
using the criterion $3 \mathrm{~s}$, was $0.02 \mathrm{ng} \mathrm{mL}^{-1}$. For the developed method this value is equivalent to $0.004 \mu \mathrm{gL} \mathrm{m}^{-1}$ in the sample. The relative standard deviation (RSD) was about $15 \%$ at the detection limit; as the concentration increased and approached ten times the DL, the precision improved in proportion. At concentration levels of from 10 to 100 times the DL, the RSD values found remained stable at approximately $1.2 \%$.

\subsection{Determination of $\mathrm{Hg}$ emission}

The mercury emission of the final solid blocks with the highest mercury content (samples Hg20SC and $\mathrm{Hg} 30 \mathrm{SC}$ ) was measured using a portable multifunctional Atomic Absorption Spectrometer with Zeeman ground correction (Mercury Analyzer Lumex RA 915). Additionally, and for comparison, a sample of natural cinnabar (ore) from the Almadén mine (provided by MAYASA) and a sample of metacinnabar obtained by direct reaction between $\mathrm{S}$ and $\mathrm{Hg}$ in stoichiometric condition were also measured. The latter sample was compacted to obtain a $5 \mathrm{~cm}$ diameter disc, in order to be able to relate the emission with the outer surface.

For these measurements, the samples were placed in a chamber of $0.22 \mathrm{~m}^{3}$ where the temperature was held at $19 \pm 2{ }^{\circ} \mathrm{C}$. All the measurements were performed after stabilizing the mercury lamp for $20 \mathrm{~min}$. Blank determinations were performed with the empty chamber for $40 \mathrm{~min}$. The measurement time was $70 \mathrm{~min}$ for each sample, up to the maximum mercuric vapor, i.e. over saturation. Figure 3 shows the scheme of the device used for mercury emission determinations.

\section{RESULTS AND DISCUSSION}

\subsection{Characterization of sulfur and thermoplastic material}

Figure 4 shows the XRD patterns for $\mathrm{S}$ and SPC. The sulfur diffractogram corresponds to the orthorhombic phase $S_{\alpha}$ (JCPDS 00-008-0247). The SPC, a plasticized concentrate called STX ${ }^{\mathrm{TM}}$, is first formulated from the polyolefin and elemental sulfur and exhibits a similar diffractogram to sulfur but with lower crystallinity. The diffraction peaks appearing at 22.8 and $27.8^{\circ}(2 \theta)$ correspond to phase $S_{\beta}$ (JCPDS 00-034-0941). These peaks can be better observed in the magnification in the top right corner of the figure.

Figure 5 (a) shows the morphological aspect of SPC, revealing a reticular structure consisting of monoclinic crystals ( $B$ phase). This structure is similar to that of phase $S_{\beta}$ observed in figure 4 . The morphological appearance of the S+SPC after heating to $145^{\circ} \mathrm{C}$ and cooling to room temperature, figure 5 (b), corresponds to the compact structure of a polymeric plastic material. In comparison with the previous case, it can be observed that the sulphur fills up the structural voids of SPC and consequently that a continuous structure was formed.

DSC curves for sulfur, SPC and the S+SPC mixture are shown in figure 6 . Two endothermic effects can be observed in these curves, corresponding to the melting of alpha $\left(S_{\alpha}\right)$ and beta $\left(S_{\beta}\right)$ phases, respectively. The first endothermic effect appears at $102.3,103.5$ and $103.6^{\circ} \mathrm{C}$ for the SPC, mixture and sulfur, respectively. The energy associated to the corresponding peaks was 4.1, 6.8 and $8.7 \mathrm{~kJ} \mathrm{~kg}^{-1}$; which means that the thermoplastic material slightly lowers the melting temperature of $\mathrm{S}_{\alpha}$ but significantly

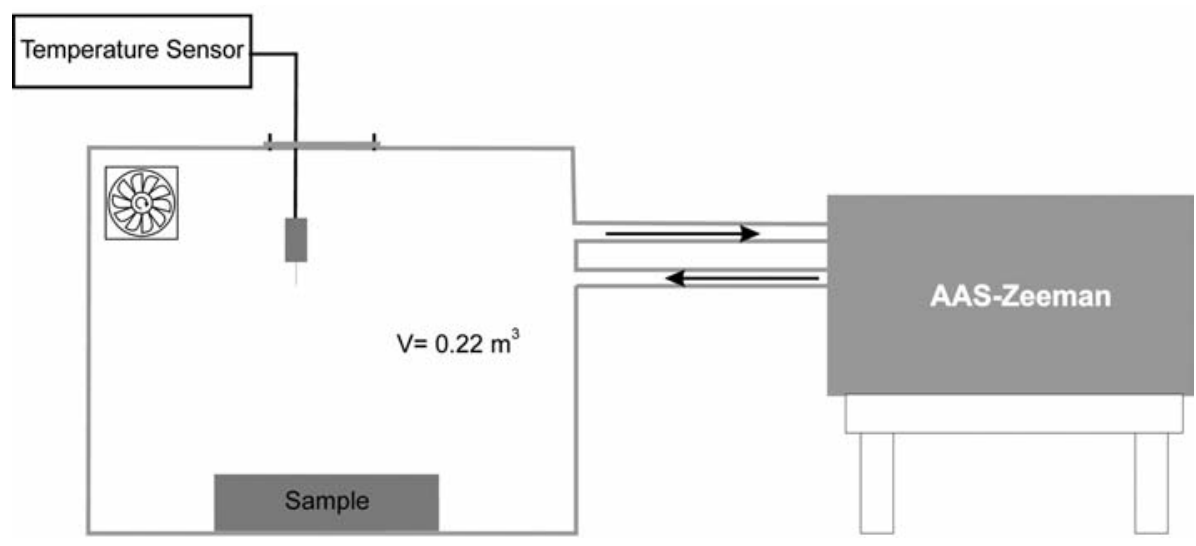

Figure 3. Device for the determination of mercury emissions.

Figura 3. Dispositivo para la determinación de las emisiones de mercurio. 


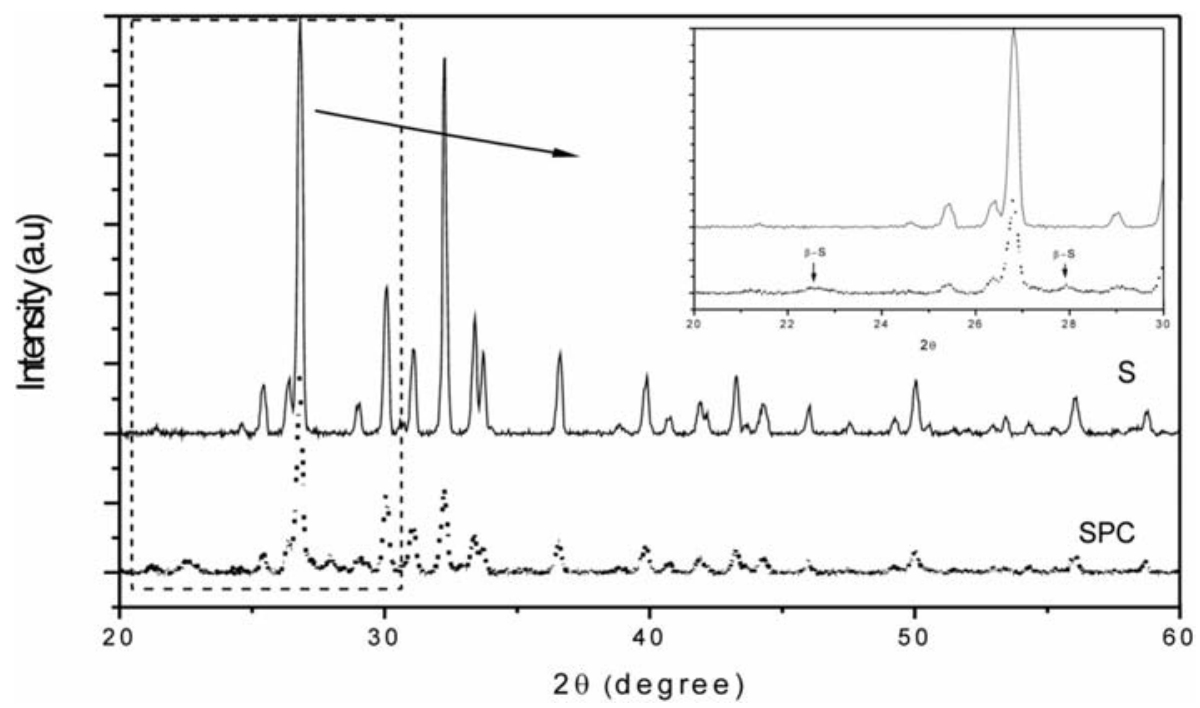

Figure 4. X-Ray Diffraction patterns for S and SPC. A magnification of the $20-30^{\circ}(2 \Theta)$ zone is shown at top right.

Figura 4. Difratogramas de rayos- $X$ del $S$ y del SPC. En la esquina superior derecha se muestra una magnificación de la zona $20-30^{\circ}(2 \Theta)$.

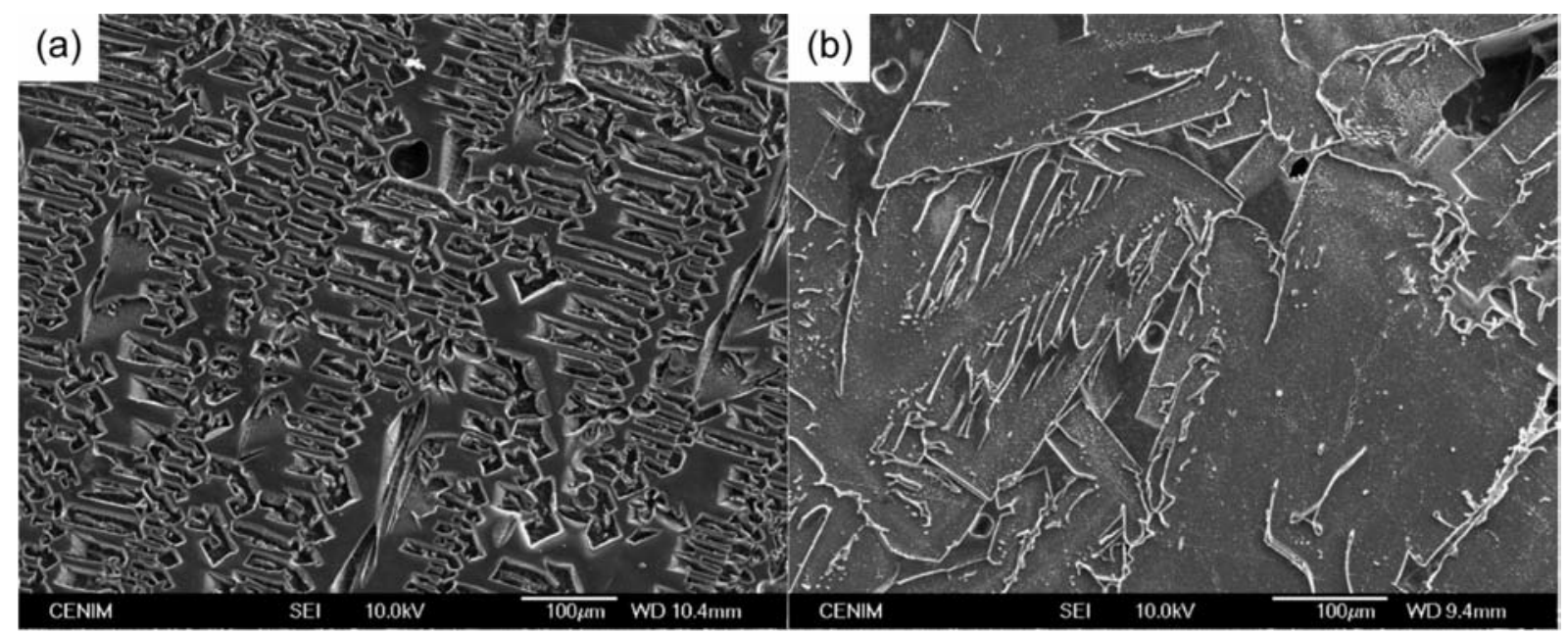

Figure 5. SEM image of a) SPC and b) the mixture of sulfur and SPC heated to $145^{\circ} \mathrm{C}$ and then cooled.

Figura 5. Imagen MEB de a) SPC y b) la mezcla de azufre y SPC calentada a $145^{\circ} \mathrm{C}$ y enfriada posteriormente.

alters the energy required for the effect to occur. With regard to the second endothermic effect, the influence of the thermoplastic material is much more important than in the previous case, and so the melting temperature values for $S_{\beta}$ are 114.7, 116.9 and $119.2^{\circ} \mathrm{C}$ for the SPC, mixture and sulfur, respectively. The corresponding energy associated to this effect is $19.6,31.7$ and $39.1 \mathrm{~kJ} \mathrm{~kg}^{-1}$, which means a decrease of nearly $8 \mathrm{~kJ} \mathrm{~kg}^{-1}$ when $10 \%$ SPC is added to the sulfur.

\subsection{Characterization of Hg-S-concrete blocks}

The aspect of the end product obtained by mercury SPSS can be seen in figure 7, in which two samples prepared with 15 and $30 \%$ mercury (samples $\mathrm{Hg} 15 \mathrm{SC}$ and Hg30SC) are shown along with the reference sample (SC).

The results for mechanical properties, compressive strength $\left(\mathrm{C}_{\mathrm{S}}\right)$ and flexural strength $\left(\mathrm{F}_{\mathrm{S}}\right)$ 


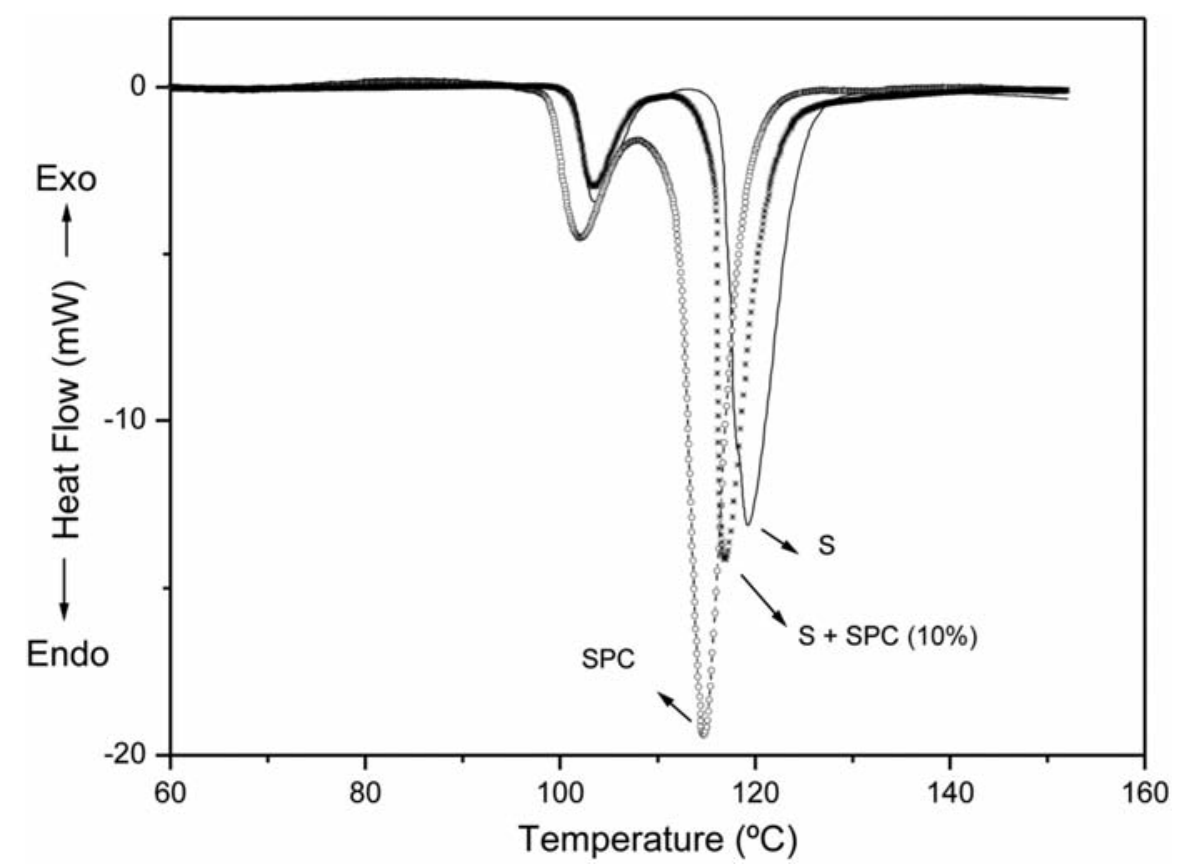

Figure 6. DSC curves for pure sulfur, modified sulfur and the S+SPC mixture (heating rate $5^{\circ} \mathrm{C} \mathrm{min}^{-1}$ ).

Figura 6. Curvas de DSC del azufre, del azufre modificado y de la mezcla $S+S P C$ (velocidad calentamiento $5^{\circ} \mathrm{C} \mathrm{min}^{-1}$ ).

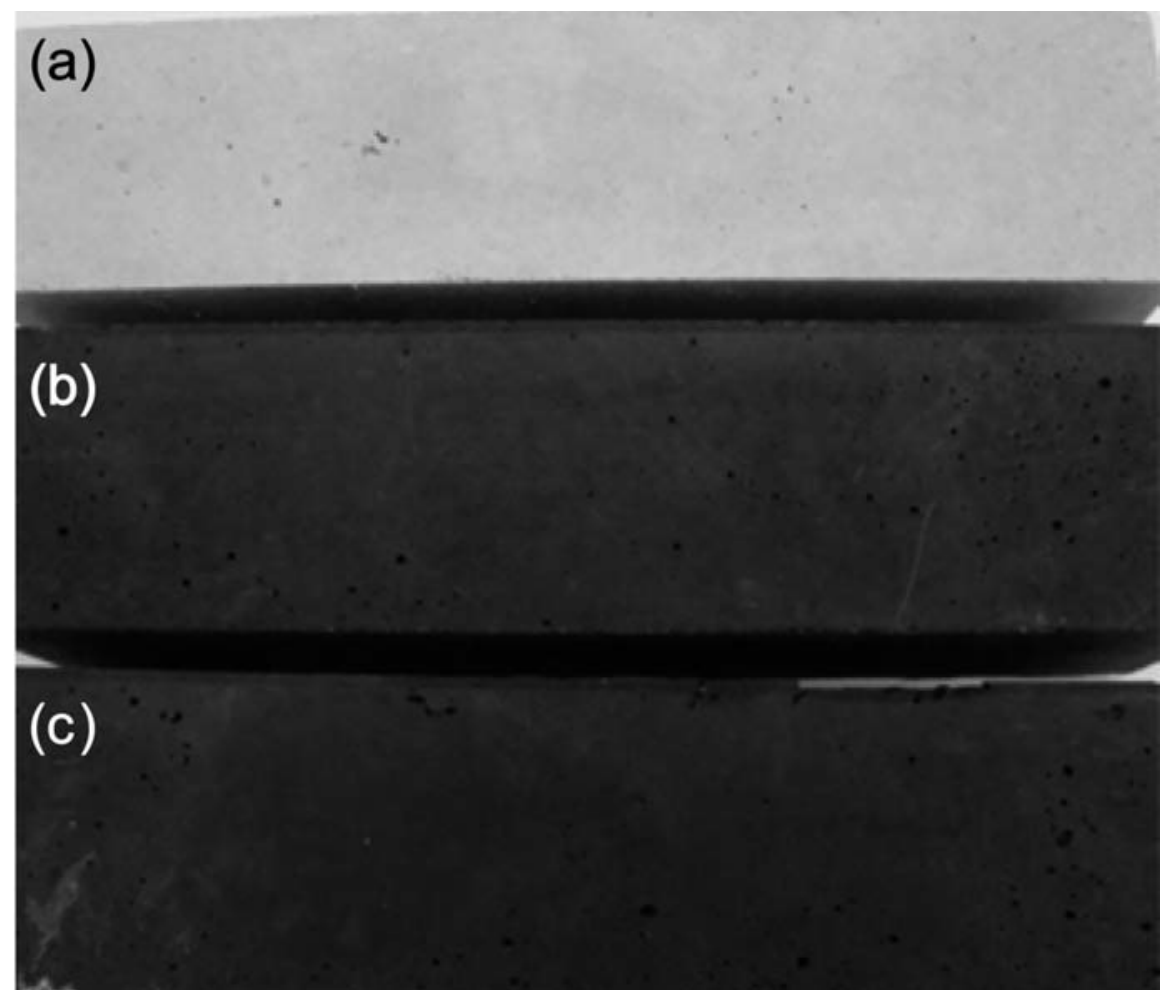

Figure 7. Solid blocks prepared by SPSS of mercury: a) reference SC, b) sample with $15 \%$ wt $\mathrm{Hg}(\mathrm{Hg} 15 \mathrm{SC})$ and c) sample with $30 \%$ wt $\mathrm{Hg}$ (Hg30SC).

Figura 7. Bloques monolíticos preparados por SPSS de mercurio: a) referencia SC, b) muestra con un $15 \%$ en peso de $\mathrm{Hg}$ (Hg15SC) y c) muestra con un $30 \%$ en peso de $\mathrm{Hg}$ (Hg30SC). 
are shown in table II. These values are quite similar to the reference values; revealing only a slight decrease in both properties as the mercury content increases. However, for the samples with a $\mathrm{Hg}$ content $>10 \%$ a certain tendency towards higher values is observed for both $\mathrm{F}_{\mathrm{s}}$ and $\mathrm{C}_{\mathrm{s}}$. These results indicate than the polymeric matrix can incorporate high mercury values (as $\mathrm{HgS}$ ) without any significant modification of mechanical properties. The compressive strength values are higher than those reported by Darnell ${ }^{[24]}$ for an SPSS process of a radionuclide waste composed of metal oxides $(\mathrm{Hg}$, $\mathrm{Pb}, \mathrm{Ag}, \mathrm{As}$ and other metals), which was $27.7 \mathrm{Mpa}$. Kalb et al. ${ }^{[25]}$ reported values ranging between 26-56 MPa for a mixed waste incinerator gas scrubbing solution.

Table II. Mechanical properties: compressive strength $\left(\mathrm{C}_{\mathrm{s}}\right)$ and flexural strength $\left(\mathrm{F}_{\mathrm{s}}\right)$

Tabla II. Propiedades mecánicas: Resistencia a compresión $\left(C_{s}\right)$ y a flexotracción $\left(F_{s}\right)$

\begin{tabular}{lll}
\hline Sample & $\mathbf{F}_{\mathbf{s}}$ (Mpa) & $\mathbf{C}_{\mathbf{s}}$ (Mpa) \\
\hline SC & $9.6 \pm 0.54$ & $58.0 \pm 2.7$ \\
Hg5SC & $9.3 \pm 0.23$ & $56.3 \pm 2.3$ \\
Hg10SC & $8.7 \pm 0.88$ & $54.8 \pm 2.8$ \\
Hg15SC & $9.6 \pm 1.03$ & $55.8 \pm 5.6$ \\
Hg20SC & $9.1 \pm 1.47$ & $58.4 \pm 4.2$ \\
Hg30SC & $8.5 \pm 1.17$ & $57.2 \pm 4.4$ \\
\hline
\end{tabular}

Table III shows the density, total pore volume and porosity values for the reference and samples obtained with 20 and $30 \%$ mercury. An increase in the density values $\left(\rho_{r}, \rho_{s}\right.$ and $\left.\rho_{b}\right)$ is observed as the mercury content rises. The porosity $\left(\mathrm{P}_{\mathrm{T}}, \mathrm{P}_{\mathrm{C}}\right.$ and $\left.\mathrm{P}_{\mathrm{He}}\right)$ and total pore volume $\left(\mathrm{V}_{\mathrm{p}}\right)$ values are lower for the samples with mercury than for the reference sample. This means that metacinnabar fills the interparticle interstices and the larger size pores (meso and macro pores) which are left in the initial S-concrete. This finding is coherent with the decrease in total porosity $\left(\mathrm{P}_{\mathrm{T}}\right)$ and total pore volume $\left(\mathrm{V}_{\mathrm{p}}\right)$ as the mercury content rises. The decrease in open porosity $\left(\mathrm{P}_{\mathrm{He}}\right)$ with the increase in mercury also fits well with the latter results.

The morphological appearance of the fracture surface of the samples can be seen in figure 8 . All the samples show an amorphous mass of sulfur and crystallized polysulfur. In the case of the reference (Fig. 8 (a)), a great agglomeration of gravel, sand and sulfur compounds as a ciliate and very compact structure were observed. Figure 8 (b) presents another micrograph of the surface, showing melted sulfur (1) distributed across the entire surface through away the surface between the calcium carbonate (2) and sand (3) and a reticular structure reminiscent of a spider's web which connects all the components (4). A magnified view of this structure is shown in figure 8 (c). The morphology of the samples obtained by the incorporation of $\mathrm{HgS}$ in the S-polymeric matrix is similar in all cases, being characterized by the presence of spheroid particles of $\mathrm{HgS}<3 \mu \mathrm{m}$ which can be agglomerated into the characteristic spider's web microstructure of the sulfur polymers. Figure 8 (d) shows SEM micrographs corresponding to sample Hg15SC, with $15 \% \mathrm{Hg}$. The ciliate structures act as a further connection between the binder and the other components, improving the microstructural continuity and the mechanical properties of the samples.

Table III. Real $\left(\rho_{\mathrm{r}}\right)$, skeleton $\left(\rho_{\mathrm{s}}\right)$ and bulk $\left(\rho_{\mathrm{b}}\right)$ density, total pore volume $\left(\mathrm{V}_{\mathrm{p}}\right)$ and total $\left(\mathrm{P}_{\mathrm{T}}\right)$, close $\left(\mathrm{P}_{\mathrm{C}}\right)$ and open $\left(\mathrm{P}_{\mathrm{He}}\right)$ porosity

Tabla III. Densidad real $\left(\rho_{r}\right)$, de esqueleto $\left(\rho_{s}\right)$ y aparente $\left(\rho_{b}\right)$, volumen total de poro $\left(V_{p}\right)$ y porosidad total $\left(P_{T}\right)$, cerrada $\left(P_{C}\right)$ y abierta $\left(P_{H_{e}}\right)$

\begin{tabular}{llll}
\hline \multicolumn{1}{c}{ Sample } & SC & Hg20SC & Hg30SC \\
\hline$\rho_{\mathrm{r}}\left(\mathrm{g} \mathrm{cm}^{-3}\right)$ & 2.5592 & 2.918 & 3.181 \\
$\rho_{\mathrm{s}}\left(\mathrm{g} \mathrm{cm}^{-3}\right)$ & 0.484 & 2.876 & 3.136 \\
$\rho_{\mathrm{b}}\left(\mathrm{g} \mathrm{cm}^{-3}\right)$ & 2.321 & 2.834 & 3.118 \\
$\mathrm{~V}_{\mathrm{p}}\left(\mathrm{x} 10^{-2}\right)\left(\mathrm{cm}^{3} \mathrm{~g}^{-1}\right)$ & 3.25 & 1.01 & 0.63 \\
$\mathrm{P}_{\mathrm{T}}(\%)$ & 7.67 & 2.88 & 1.97 \\
$\mathrm{P}_{\mathrm{C}}(\%)$ & 2.93 & 1.44 & 1.40 \\
$\mathrm{P}_{\mathrm{He}}(\%)$ & 4.74 & 1.44 & 0.57 \\
\hline
\end{tabular}



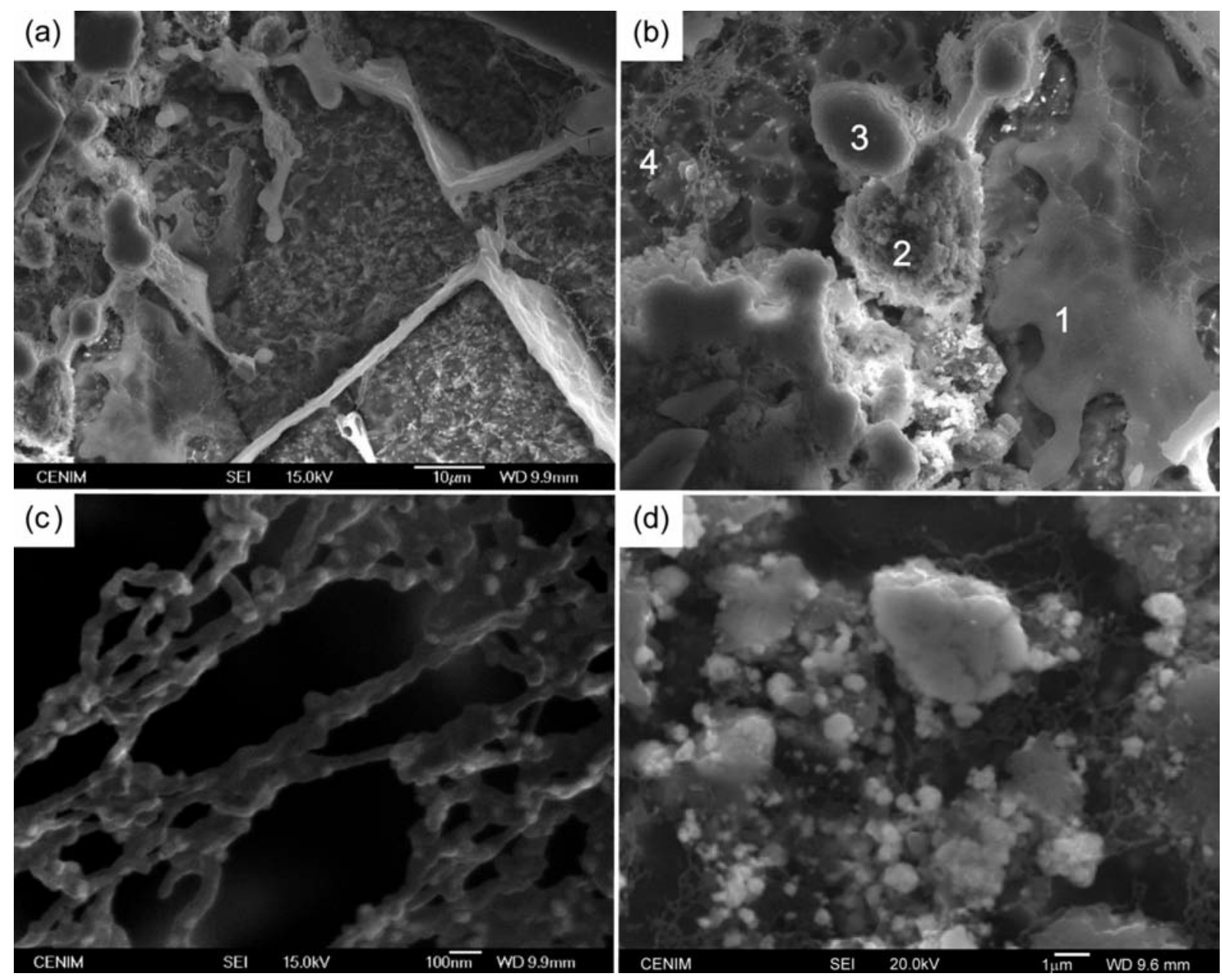

Figure 8. SEM micrographs of polished fracture surface of reference (a, b and c) and $\mathrm{Hg} 15 \mathrm{SC}$ (d).

Figura 8. Imágenes MEB de la superficie de fractura pulida de la muestra de referencia (a, b y c) y de la muestra Hg15SC (d).

\subsection{Mercury leaching test}

Concerning the results of the TCLP test ${ }^{[22]}$, figure 9 shows the mercury values in the leachates corresponding to all the samples. This figure also shows the mercury concentration limit in leachates established in the US EPA Land Disposal Restrictions Regulations for Mercury-Containing non-wastewaters (LDRs) ${ }^{[26]}$. In general, it can be seen that the mercury content in the solution increases with the mercury content in the samples. Nevertheless, even for the sample with $30 \%$ mercury content the mercury concentration in the leachate is much lower than $0.2 \mathrm{mg} \mathrm{L}^{-1}$, as established in LDRs. For comparative purposes a sample of the initial liquid mercury was subjected to the TCLP test, and the mercury content in the solution was $8960 \mathrm{mg} \mathrm{L}^{-1}$.

It should be pointed out that the performance of the TCLP test required the samples to be crushed to a grain size of less than $0.5 \mathrm{~mm}$, and it is difficult to

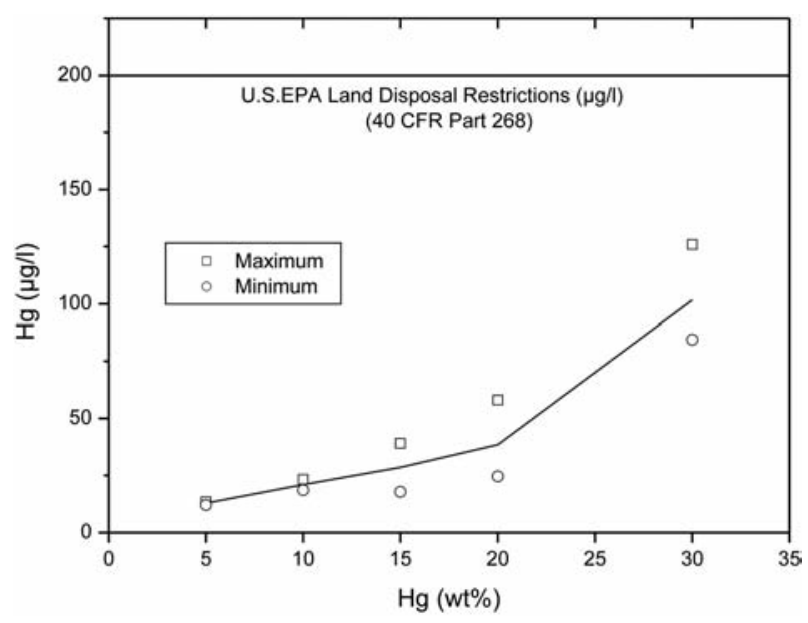

Figure 9. Results of TCLP test and comparison to LDRs ${ }^{[27]}$.

Figura 9. Resultados de los ensayos de lixiviación TCLP y comparación con las LDRs ${ }^{[27]}$. 
Table IV. Mercury emissions for sample Hg20SC, Hg30SC, cinnabar and metacinnabar

Tabla IV. Emisiones de mercurio de las muestras Hg20SC, Hg30SC, cinabrio y metacinabrio

\begin{tabular}{|c|c|}
\hline Sample & [Hg] $\left(\mathrm{ng} \mathrm{m}^{-3}\right)$ \\
\hline Air (blank) & 77 \\
\hline Hg20SC & 233 \\
\hline $\mathrm{Hg} 30 \mathrm{SC}$ & 164 \\
\hline Cinnabar (ore) & 25539 \\
\hline Metacinnabar & 3220 \\
\hline
\end{tabular}

know whether this huge size reduction affects the mechanism of the microencapsulation process and thus the true effectiveness of the SPSS process. Despite this assumption, all the samples passed this test, even with mercury content as high as $30 \%$. Values ranging between $0.020-0.40 \mathrm{mg} \mathrm{L}^{-1}$ are reported by Fuhrmann et al. ${ }^{[17]}$ for the leachates of radioactive $\mathrm{HgO}$ wastes microencapsuled using a SPSS process.

\subsection{Mercury emissions}

Mercury emission values were studied for the $\mathrm{Hg}$-S-concrete blocks with the highest mercury content, i.e., samples with 20 and $30 \%$ mercury. For comparison, mercury emissions of metacinnabar and cinnabar were also measured. Table IV sets out the mercury emission values expressed as ng $\mathrm{Hg}$ per air volume. Samples Hg20SC and Hg30SC showed very much lower mercury emission values than cinnabar (100 - 150 times lower) and metacinnabar (15 - 20 times lower).

The low mercury emissions for samples Hg20SC and $\mathrm{Hg} 30 \mathrm{SC}$ compared to metacinnabar are much lower than may be expected just from consideration of the dilution effect. This may mean that the S-concrete matrix produces a screening effect and thus decreases the mercury emission.

Figure 10 shows the variation in the mercury concentration in air as a function of time. Two stages can be observed, the first $(0<\mathrm{t}<1500)$ faster than the second $(1500<t<4000)$, which is where the equilibrium is attained.

From the slope of the different curves for the time period $0<\mathrm{t}<1500$, the value of the apparent emission rate $\left(\mathrm{V}_{\mathrm{e}}\right)$ was determined (Table $\left.\mathrm{V}\right)$. It can be observed that $\mathrm{V}_{\mathrm{e}}$ for metacinnabar is 15 and 40 times higher than that of samples Hg20SC and $\mathrm{Hg} 30 \mathrm{SC}$. In the case of cinnabar this value is even higher. The mercury emission was also calculated according to the mercury content in each sample. These results are also shown in table $\mathrm{V}$, expressed as ng $\mathrm{Hg}$ per $\mathrm{g} \mathrm{Hg}$ total in the sample. From these results it was possible to relate $\mathrm{V}_{\mathrm{e}}$ to mercury emission by means of equation (5), where: $K$ and $a$ are numerical constants and $\mathrm{C}$ is the relationship between the

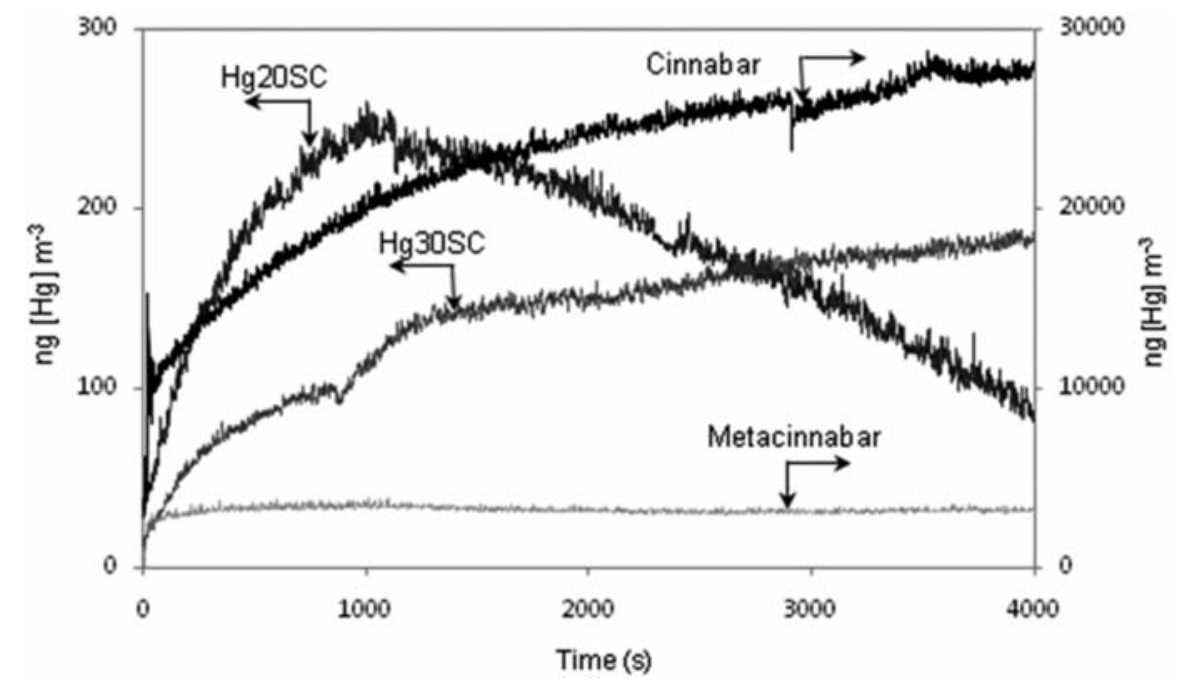

Figure 10. Variation in mercury emission with time for $\mathrm{Hg} 20 \mathrm{SC}, \mathrm{Hg} 30 \mathrm{SC}$, cinnabar and metacinnabar.

Figura 10. Variación de las emisiones de mercurio en función del tiempo para las muestras Hg20SC, Hg30SC, cinabrio y metacinabrio. 
Table V. Velocity of mercury emission $\left(\mathrm{V}_{\mathrm{e}}\right)$ and emission per mercury content in the samples

\section{Tabla V. Velocidad de emisión de mercurio $\left(V_{e}\right)$ y emisión por contenido de mercurio en las muestras}

\begin{tabular}{|c|c|c|}
\hline Sample & $\begin{array}{c}V_{\mathrm{e}} \times 10^{3} \\
\left(n g \mathrm{~m}^{-3} \mathrm{~s}^{-1}\right)\end{array}$ & $\begin{array}{l}\mathrm{Hg} \text { Emission } \\
\left(\mathrm{ng} \mathrm{g}^{-1}\right)\end{array}$ \\
\hline Cinnabar & 21.32 & 1179.1 \\
\hline Metacinnabar & 3.20 & 148.7 \\
\hline Hg20SC & 0.21 & 10.75 \\
\hline Hg30SC & 0.08 & 7.57 \\
\hline
\end{tabular}

mercury emission and the total mercury content in the sample expressed as $\mathrm{ng} \mathrm{g}^{-1}$.

$$
V_{e}=K \cdot e^{a \cdot C}
$$

The values of mercury emission per surface unit, expressed as $\mathrm{ng} \mathrm{m}^{2}\left(\mathrm{x} 10^{3}\right)$, were $545,78.64$ and 67.44 for metacinnabar, Hg30SC and Hg20SC, respectively. This value was not calculated for cinnabar because of the irregular surface of the ore sample. These results indicate that the SPSS process developed here assured lower mercury emissions than cinnabar or metacinnabar.

\section{CONCLUSIONS}

- The two-step SPSS process developed for the microencapsulation of liquid mercury minimizes the oxidation of mercury to mercuric oxide because metacinnabar formation is carried out at low temperature, and also minimizes the amount of mercury which has not reacted in the first stage thanks to the extra sulfur content in the medium in the second stage. The proper size distribution matching of the aggregates, the fine metacinnabar and the right choice of the manufacturing technological process yielded concrete-like particulate materials with extremely low porosity, a tight microstructure and high flexural and compression strength, in which high amounts of mercury (up to $30 \%$ ) can be incorporated.

- The monolithic end product exhibits very low mercury vapor emission and very low mercury leachability. Thus the process developed stabilizes and solidifies liquid mercury by rendering inert materials and allowing the long-term storage of this waste.

\section{ACKNOWLEDGEMENTS}

The authors thank Mr. C. Pérez Roman (CSIC) for his technical assistance, the LIFE Project (LIFE06/ENV/ES/PRE/03) for its financial support and the project partners Minas de Almadén y Arrayanes S.A., and University of Castilla-La Mancha (specially Drs. J.M. Esbrí and P.L. Higueras) for their collaboration. The authors also thank Institute of Applied Geology of UCLM for lending the Mercury Analyzer Lumex RA 915.

\section{REFERENCES}

[1] UNEP, Draft technical guidelines on the environmentally sound management of mercury wastes, $4^{\text {th }}$ Draft, April, 2009. http://www.basel. int/techmatters/mercury/guidelines/040409.doc

[2] Directive 2000/60/EC of the European Parliament and of the Council of 23 October 2000 establishing a framework for Community action in the field of water policy, Official Journal. L 327, (22/12/2000), 0001-0073.

[3] Regulation (EC) No 1102/2008 of the European Parliament and of the Council of 22 October 2008 on the banning of exports of metallic mercury and certain mercury compounds and mixtures and the safe storage of metallic mercury, Official Journal of the European Union. L 304 (14/11/2008), pp. 75-79.

[4] T. Brasser. Mercury storage in Europe and Germany Regulations and General Conditions on "Mercury Storage Project Inception Workshop" Bangkok, Thailand, March 4-5. 2009. http://www.chem.unep.ch/mercury/ storage/GRS-Germany\%20T\%20Brasser.pdf

[5] European Commission, Brussels, Requirements for facilities and acceptance criteria for the disposal of metallic mercury, Bipro, Final Report, 16, April, 2010.

[6] M. Svensson, B. Allard and A. Düker, Sci. Total Environ. 368 (2006) 418-423.

[7] F.A. López, A. López-Delgado, I. Padilla, H. Tayibi and FJ. Alguacil, Sci.Total Environ. 408 (2010) 4341-4345.

[8] e-CFR. 40 Protection of Environment. I Environmental Protection Agency. I Solid Wastes. Part 268 Land Disposal Restrictions, subpart D 268.42 Treatment standards expressed as specified technologies. http://cfr.vlex.com/ vid/268-expressed-specified-technologies19820104

[9] P. Randall and S. Chattopadhyay, J. Hazard. Mater. B114 (2004) 211-223. 
[10] R. Malviya and R. Chaudhary, J. Hazard. Mater. B137 (2006) 267-276.

[11] J.M. Zhuang, T. Lo, T. Walsh and T. Lam, J. Hazard. Mater. B113 (2004) 157-164.

[12] X.Y. Zhang, Q.C. Wang, S.Q. Zhang, X.J. Sun and Z.S. Shang, J. Hazard. Mater. 168 (2009) 1575-1589.

[13] H. Vroom, Sulfur cements, process for making same and sulfur concretes made therefrom. Patent US 4058500 (1977).

[14] STARTcrete ${ }^{\mathrm{TM}}$ Technologies Inc. laboratory procedure for producing STARcretes ${ }^{\mathrm{TM}}$ test specimens. Tehnical Report, 2000.

[15] M.M. Jonhson, M. Simfukwe, G.P. Nowack and D.H. Kubiced, Patent US 5360632 (1994).

[16] P.D. Kalb, D. Melamed, B.R. Patel and M. Fuhrmann, Patent US 6399849 (2002).

[17] M. Fuhrmann, D. Relamed, P.D. Kalb, J.W. Adams and L.W. Milina. Waste Manage. 22 (2002) 327-333.

[18] F.A. López, A. López-Delgado, FJ. Alguacil and M. Alonso, Spanish Patent P200930672 (2009).

[19] A. López-Delgado, F.A. López, C. Pérez, F.J. Alguacil, A. Conde, M. Ramos and P. Higueras, $9^{\text {th }}$ International Conference on Mercury as a Global Pollutant, Ghuizhou, China, 2009, pp.

[20] Real Decreto 2661/1998, de 11 de diciembre, por el que se aprueba la Instrucción Española del Hormigón Estructural (EHE), BOE num.11 (13/01/1999) 1525-1526.
[21] UNE EN 196-1:2005. Métodos de ensayo de cementos. Parte 1: Determinación de resistencias mecánicas, 2005.

[22] TCLP, EPA Method 1311. Toxicity Characteristic Leaching procedure, http://www. epa.gov/osw/ hazard/testmethods/sw846/pdfs/1311.pdf

[23] EPA Method 7474. Mercury in sediment and tissues samples by atomic fluorescence spectrometry, http://www.epa.gov/osw/hazard/testmethods/sw846/pdfs/7474.pdf

[24] G.R. Darnell. Stabilization and Solidification of Hazardous, Radioactive, and Mixed Wastes, T. Michael Gillian and Carlton C. Willes (editors), vol. 3, American Society for Testing and Materials, West Conshohocken, PA, 1996, pp. 272-283.

[25] P.D. Kalb, J.W. Adams, M.L. Meyer and H.H. Burns, Stabilization and Solidification of Hazardous, Radioactive, and Mixed Wastes, T. Michael Gillian and Carlton C. Willes (editors), vol. 3, West Conshohocken, PA, 1996, pp. 327-340.

[26] US EPA Land Disposal Restrictions Regulations for Mercury-Containing Non-wastewater. http://www.epa.gov/osw/hazard/wastetypes/universal/lamps/faqs.htm

[27] Mercury Laws and Regulations. Land Disposal Restrictions Regulations for MercuryContaining Waste. http://www.epa.gov/mercury/regs.htm\#wastes 